\title{
PERCEPTIONS OF CRIMINAL INJUSTICE, SYMBOLIC RACISM, AND RACIAL POLITICS
}

\author{
Ross L. Matsueda \\ Department of Sociology \\ University of Washington \\ 223J Condon Hall, Box 353340 \\ 1100 NE Campus Parkway \\ Seattle, WA 98195-3340 \\ Ph:. 206-616-2432 \\ FAX: 206-543-2516 \\ matsueda@u.washington.edu \\ Kevin Drakulich \\ Department of Sociology \\ University of Washington \\ 223J Condon Hall, Box 353340 \\ 1100 NE Campus Parkway \\ Seattle, WA 98195-3340 \\ Ph: 206-543-5882 \\ FAX: 206-543-2516 \\ kmd3@u.washington.edu
}

Key Words: Perceived Criminal Injustice, Racism, Laissez-Faire Racism, Symbolic Racism, Racial Politics, Affirmative Action

An earlier version of this article was presented at the Racial Democracy, Crime and Justice Network Summer Workshop, Columbus, OH, 2007. The research upon which this article is based was supported by grants from the National Science Foundation (SES-0004324, SES-0731473), the National Consortium on Violence Research (SBR-9513040), and the American National Elections Studies 2006 Pilot Study. The funding agencies bear no responsibility for the analyses and conclusions drawn here. The authors thank John Hagan, Lauren Krivo, Ruth Peterson, and the Racial Democracy, Crime, and Justice Network for helping to launch the project upon which this article is based, as well as Stewart Tolnay, Lauren Krivo, and Ruth Peterson for comments on an earlier draft, and Aimée Dechter and Robert Crutchfield for helpful advice. 


\title{
PERCEPTIONS OF CRIMINAL INJUSTICE, SYMBOLIC RACISM, AND RACIAL POLITICS
}

\begin{abstract}
This article examines the relationships among perceptions of criminal injustice, symbolic racism, and political outcomes. Building on a group conflict theory of social control and a group position theory of contemporary racism, we hypothesize that perceptions of criminal injustice against blacks undermines the legitimacy of social institutions, such as free markets and the legal system, and encourages support for progressive programs, such as affirmative action, to ameliorate the effects of racial discrimination. We further hypothesize that perceptions of criminal injustice influence support for these progressive programs by undermining symbolic racist attitudes. Using data from the American National Election Survey, we find preliminary evidence for this perspective. Perceived police racial bias is negatively associated with symbolic racism, which, in turn, is negatively associated with affirmative action, equal opportunity policy, and government action to ensure equal opportunity, and positively associated with support for the death penalty and crime spending.
\end{abstract}


Issues of race and crime often play a crucial role in American electoral politics. Who can forget the explosive result of George H. W. Bush's "Willie Horton" campaign ads, which drew on the intersection of racism and irrational fears of crime, during the 1988 presidential campaign? Who can forget Jesse Helm's 1990 campaign ads showing a white male losing his job because of a racial quota? And who can forget the beating Rodney King took at the hands of four white Los Angeles police officers, the international outrage, and riots that followed the officers' acquittal of criminal charges? Racial politics became particularly salient with the 2008 presidential candidacy of Barack Obama, the first African-American to win a major party nomination. Notably, a nontrivial minority of white Americans state that they would not vote for Obama for president simply because of his race. Thus, prejudice and racism persist in contemporary America and continue to play a prominent role in electoral politics (e.g., Sears, Henry, and Kosterman 2000).

Racism may also play a role in undermining the legitimacy of the criminal justice system (Bobo and Thompson 2006; Tyler 2003). Recent Gallup polls suggest that as few as one-quarter of Americans have a great deal or quite a lot of confidence in our legal system. This finding is troubling. To maintain the consent of the governed, it is essential that citizens view conventional institutions as fair, just, and trustworthy. Perhaps the most crucial institution for maintaining legitimacy of government is the legal institution, which is concerned with administering justice, maintaining order in civil society and inflicting state-legitimated punishment. Indeed, the criminal justice system may be the most salient point of contact with government institutions for large segments of the population, particularly the disadvantaged, the poor, and racial and ethnic minorities. If citizens view the system of justice as unjust, the social and political system is likely to be volatile and unstable. In the United States, perceptions of criminal injustice appear to differ markedly by race, ethnicity, and social class (e.g., Hagan and Albonetti 1982; Hagan, Shedd, and Payne 2005).

This article draws on group conflict theories to examine the intersection of criminal injustice, contemporary racism, and racial politics. Group conflict theories of crime argue that dominant groups maintain hegemony over subordinate groups by using the legal system to realize their interests (e.g., Turk 1969). Bias against the poor, minorities, and otherwise disenfranchised groups is viewed as endemic to criminal justice. Theories of racism as a sense of group position emphasize the role of group interests and political power, but also stress the role of feelings of antipathy and negative imagery in processes of prejudice and racism (e.g., Blumer 1958). Drawing on these perspectives, we hypothesize that widespread beliefs that the police are biased against blacks undermine conventional institutions, trigger efforts to reform institutions with policies such as affirmative action, and ultimately affect electoral politics. We further hypothesize a black-white racial component to this process. African Americans are more likely to believe that police are biased against blacks, less likely to buy into prejudicial beliefs, and more likely to favor policies like affirmative action. White Americans may be more likely to believe that the police are fair, maintain prejudicial beliefs, sustain cynicism about affirmative action, and oppose liberal race-targeted policies. Below, we introduce a model of injustice, racism, and political outcomes that allow us to test our hypotheses using data from the American National Election Survey (ANES).

\section{RACE AND PERCEPTIONS OF CRIMINAL INJUSTICE}

Broadly speaking, citizens' beliefs in the fairness of the legal system is essential for maintaining the legitimacy of the social order. According to Weber (1978), procedural justice helps legitimize the social order, thereby increasing the likelihood that citizens will see the system as fair and 
follow its rules. Building on Weber, Tyler $(1990,2003)$ developed a "process-based" model of procedural justice, in which the legitimacy of legal authorities is rooted in the "public's judgment that the police and the courts are acting fairly when they deal with community residents" (2003:286). Such legitimacy is central to conflict theorists' arguments that crime control in the U.S. is rooted in power differentials, group threat, and competition (e.g., Hagan et al. 2005).

Research has established that a soaring number of African Americans are coming into contact with the criminal justice system and viewing it as unjust. In contrast, white Americans are less likely to come before the legal system and more likely to view it as fair (e.g., Bobo and Johnson 2004; Brooks and Jeon-Slaughter 2001; Hagan and Albonetti 1982). The former undermines legitimacy, while the latter reaffirms it.

Group differences in perceived criminal injustice may produce political conflict, divergent interests, and competing ideologies. This is particularly likely when group boundaries reflect existing factions that have a long history of conflict. Race is such a case. Thus, we anticipate racial differences in assessments of bias in the legal system. Whites may be less likely to have negative experiences with the police, and to know of others who have such experiences. By contrast, African Americans may be more likely to experience racial bias by the police and to have friends and family who have been treated unfairly by authorities. Regardless of group membership, we expect perceptions of criminal injustice to undermine the legitimacy of the social system, including social institutions like the free market economy, the legal system, and the education system. We focus on political outcomes, hypothesizing that a belief that the police are unfair to blacks will draw into question the legitimacy of conventional institutions, creating cynicism over the capacity of government programs to combat crime and skepticism over the ability of free markets to ensure equal opportunities. We hypothesize that one of the causal mechanisms is contemporary racism.

\section{CONTEMPORARY PREJUDICE AND RACISM}

\section{Prejudice as a Sense of Group Position}

Blumer (1958) argues that prejudice is not merely a set of feelings of antipathy or hate, or solely a set of psychological predispositions, but rather is socially rooted in the relative position of groups. Prejudice arises from a collective process by which members of a dominant group define and redefine subordinate groups, and, in the contrast, define their own relative group position and group identity. Blumer (1965) uses the term, popularized by DuBois ([1903]1973), "the color line" to represent this collective definition applied to blacks and whites, which is multi-layered and entails two axes: domination-subordination and inclusion-exclusion. Although prejudice is not merely a set of feelings, Blumer identifies four feelings or images that tend to constitute prejudice: an image of the subordinate group as inherently different or alien; a feeling of superiority over the subordinate group; a proprietary claim to privilege or advantage over the subordinate group; and most importantly, a sense that the position of the dominant group is threatened by the subordinate group. Therefore, racial prejudice is a defensive reaction by dominant groups to perceived challenges to their group position by subordinate groups. Moreover, prejudice is not merely a symbolic emotional response (see Kinder and Sears' (1981) notion of symbolic prejudice), but is also rooted in the historical evolution of material conditions that define groups' positions vis-à-vis each other (e.g., Bobo 1983), a process which Bonilla-Silva (1997) terms, "racial contestation." 


\section{From Jim Crow to Laissez-Faire Racism}

Bobo et al. (1997) use the term, "laissez faire racism," which contrasts with Jim Crow racism, to emphasize that modern racism is no longer overt, rooted in beliefs about biological superiority, or institutionalized in blatantly racist systems such as slavery, segregation, or Jim Crow laws. Instead, contemporary racism is covertly embedded in valued American institutions such as free markets and ideologies such as equal opportunity. A combination of structural changes in the U.S. economic and political systems - which changed incentives and interests with respect to race relations - and the successes of the civil rights movement of the 1960s undermined Jim Crow racism (Bobo et al. 1997; Omi and Winant 1994).

The result was neither a color-blind society nor the end of racism and prejudice. Instead, racism has taken new forms, which are covert, institutionalized, and consonant with cherished American values such as hard work, individualism, and democracy (Bobo et al. 1997). This "new racism" argument has two components. First is the assertion that, because of the historical legacy of Jim Crow racism, the intergenerational transmission of disadvantage including social, cultural, and human capital, and the persistence of some contemporary racism in less discernible forms, African-Americans begin at a competitive disadvantage at birth. Second is the observation that many Americans are blind to these differences, and consequently oppose governmental policy to ensure equal opportunity, including affirmative action (Kinder and Mendelberg 2000; Kinder and Sears 1981). For Blumer (1965:330), the civil rights movement peeled away the outer layer of the color line but scarcely scratched the inner layer of "economic subordination and opportunity restriction," and left unscathed the "inner citadel of inclusion" by admission into intimate social circles, friendships, families, and marriage.

Three empirical implications derive from this discussion. First, contemporary racism takes two forms: (1) laissez-faire, where dominant groups dismiss evidence of historical, overt racial discrimination and assume that subordinate groups can pull themselves up by their bootstraps; (2) explicit, based on negative racial stereotypes in which the legacy of Jim Crow racism persists among a small portion of dominant groups. Second, in advanced capitalism, particularly when free market ideologies predominate, laissez-faire racism should resonate well, justifying the dominance of groups of advantaged whites. Third, laissez faire racism should be a more powerful predictor of contemporary racial politics than explicit racism.

Sniderman and Carmines (1997) argue that the claims of the new racism are due less to racism and more to a principled opposition to government intervention. Empirical evidence on this claim is equivocal (e.g., Schuman et al. 1997; Sniderman and Piazza 1993), but the "principled opposition" perspective underscores the importance of controlling for the effects of opposition to government intervention when examining racial attitudes and their consequences. Perceptions of Criminal Injustice and Formation of Individual Racist Beliefs Research suggests that racism is learned early in life, through socialization in the family, peer groups, and mass media, and then becomes relatively resistant to change (e.g., Sears and Henry 2003, 2005). Such effects are likely to vary by individuals'own race-ethnicity and by social class. But racism is not a perfectly-stable personality trait, and is likely to evolve through one's life course, as one adapts to changing social roles, adjusts to changing social trends in racial attitudes, and updates beliefs based on personal observations or experiences of institutions treating subordinate groups unfairly. We hypothesize that perceived criminal injustice against blacks in part shapes racist beliefs among both blacks and whites. A strong belief that police treat blacks fairly allows individuals to maintain prejudicial attitudes, and in turn, to oppose liberal policies, such as affirmative action and support conservative policies that have a racial hue, such as the 
death penalty. By contrast, a strong belief that police treat blacks unfairly undermines racist beliefs, and motivates individuals to support affirmative action and oppose the death penalty.

In sum, racist beliefs, particularly laissez-faire racism, may provide a mechanism by which perceptions of criminal injustice against minorities are linked to racial politics. These relationships form a conceptual model with two features (see Figure 1). First, it provides a mechanism explaining racial differences in political behavior. Because of learning from family and friends, and their own personal experiences with the system, blacks are more likely to perceive the justice system as biased against blacks, which in turn, motivates them to favor ameliorative policies like affirmative action and oppose racially-charged policies like capital punishment. Compared to blacks, whites are more likely to espouse laissez faire racism, fostering opposition to affirmative action policies. Second, it provides a mechanism by which perceptions of criminal injustice lead to political behavior: perceived racial injustice undermines racist attitudes which foster support for affirmative action and opposition to capital punishment.

\section{DATA, MODELS, AND HYPOTHESES}

\section{Data and Measures: American National Election Survey}

We use data from the merged 2004 Time Series and 2006 Pilot Studies from the American National Election Survey. Using a multi-stage area probability sampling design to represent the adult population of the United States, the 2004 ANES Study interviewed 1,212 adults yielding a response rate of 66.1 percent. In the fall of 2006, following the U.S. midterm elections, the 2006 Pilot study followed up with interviews of 675 of the 2004 sample, for a re-interview rate of 56.3 percent. The merged file provides complete data on the 675 respondents who participated in both studies. The analyses use the ANES-constructed sample weights, which incorporate sampling, non-response, and post-stratification factors. (Table 1 presents measures and descriptive statistics.)

Our measures of key concepts, drawn from the ANES surveys (www.electionstudies.org/studypages/download/datacenter_all.htm), have been well-scrutinized and found to have reasonable measurement properties. We use four measures of contemporary racism to capture symbolic racism (see e.g., Sears, Henry, and Kosterman 2000). These items contain both a structural component (e.g., "Slavery and discrimination have made it difficult for blacks") and an individual component (e.g., "Blacks should overcome prejudice without special favors"). Explicit racism is measured by three stereotypes - each asked about whites and blacks separately - measured on seven-point scales: hardworking-lazy, intelligent-unintelligent, trustworthy-untrustworthy. To get at the relative stereotyping of blacks versus whites, we subtracted the white stereotypes from the black stereotypes. The correlation between symbolic racism and explicit racism is .41 , suggesting that symbolic racism is capturing an affective, stereotypic component, but also showing discriminant validity from explicit stereotyping.

Our measures of black-white police injustice have been used extensively (e.g., Hagan and Albonetti 1982; Hagan et al. 2005). "What percent of suspects are treated fairly by the police?" was asked about both blacks and whites. To measure relative injustice, we subtracted white from black police injustice. Therefore, a one-unit increase in black-white police injustice implies the belief that one percent more black than white suspects are treated unfairly by police.

The models control for political variables known to be associated with political behavior, including conservative political ideology and identification with the Republican Party (both measured on seven-point Likert scales), as well as a minimize government index comprised of three measures $(\alpha=.73)$ : "Government is growing by involving itself in things people should do for themselves;" "Strong government, rather than the free market, is needed to handle today's 
economy;" and "Less government is better." This allows us to test the hypothesis that it is a desire for minimal government rather than symbolic racism that drives racial politics.

We examine five political outcomes. Equal opportunity measures belief in the desirability of equal opportunity in society, and is an index of six items $(\alpha=.74)$, such as "Society should do whatever is necessary to make sure that everyone has an equal opportunity to succeed." We have two measures of affirmative action. Affirmative action (a dichotomous variable) captures the principle of affirmative action for blacks in hiring and promotion decisions; government ensure fairness ("Should government ensure that blacks get fair treatment in jobs") asks whether the government should be involved. We examine two single item concepts related to crime: support for the death penalty for convicted murderers, and crime spending (a dichotomous variable) which asks whether federal spending on crime should be increased.

\section{Models and Hypotheses}

We first examine the hypothesis that blacks and members of lower classes perceive greater police bias against blacks relative to whites. We then examine the effects of race and police injustice on each of our five political outcomes. We use linear regressions for outcomes assumed to be continuous and logistic regressions for dichotomous outcomes. We hypothesize that, compared to whites, blacks will be more supportive of equal opportunity programs, more opposed to the death penalty because of its discriminatory use, but more in favor of crime spending because AfricanAmericans are more likely to be victims of crime (e.g., Meares and Kahan 1998). Perceptions of police injustice should undermine the legitimacy of institutions, and therefore be positively associated with programs designed to ensure equal opportunity and negatively associated with the death penalty.

Next, we estimate the full model and test the following hypotheses regarding racism's consequences for political outcomes: (1) symbolic racism, which captures contemporary racial resentment, has stronger negative effects on political outcomes than explicit racism based on black stereotypes: (2) symbolic racism, but not explicit racism, is positively associated with support for the death penalty and increased crime spending; and (3) the effects of symbolic and explicit racism reflect principled opposition to government intervention, rather than contemporary forms of racism (Sniderman and Carmines 1997). Finally, we examine the extent to which symbolic racism mediates the effects of police injustice, and the extent to which the model as a whole explains black-white differences in political outcomes.

\section{RESULTS}

We begin by regressing police injustice on demographic and political variables (Table 2). On average, compared to whites, African Americans believe that police treat seven percent more blacks unfairly than whites. The corresponding estimate for females, relative to males, is five percent. We also find that black-white police injustice is negatively associated with conservative ideology, age, and married and positively associated with socioeconomic status (SES).

Table 3 regresses explicit racism, and symbolic racism on police injustice and control variables. We find support for the hypothesis that perceived black-white police injustice undermines both explicit and symbolic racism. The effect is particularly strong for symbolic racism: the standardized coefficient of police injustice (-.22) is the largest of the model. As expected, on average, whites and those who are more strongly Republican score higher on both scales than their black and less strongly Republican counterparts. But net of race, party affiliation, 
and other variables, SES is negatively associated with racism, an effect perhaps driven by education. The models also explain more variance in symbolic (.37) than explicit racism (.15).

Table 4 presents OLS regression estimates of models of political outcomes measured on interval scales: government ensure fairness and equal opportunity, and favor the death penalty. We focus on three questions: (1) Are there black-white differences in political outcomes? (2) Are perceptions of black-white police injustice associated with political outcomes? (3) Is racism associated with political outcomes, and if so, does it explain the effects of race and police injustice on political outcomes? For each outcome, we report two models: model 1 includes demographics, political controls, and police injustice; model 2 adds explicit and symbolic racism.

Model 1 reveals that, compared to whites, African-Americans on average are more in favor of government ensuring fairness, equal opportunity, and more against the death penalty. Also respondents with higher SES tend to favor equal opportunity and oppose the death penalty, again perhaps due to education. As expected, preference for small government is negatively associated with government ensure fairness and equal opportunity. This underscores the importance of controlling for attitudes toward minimal government when examining political outcomes. Also conservative ideology is negatively associated with government ensure fairness and equal opportunity, and positively associated with favor the death penalty. Moreover, as hypothesized, net of these political variables, police injustice is significantly associated with all three outcomes in the expected direction. The effects are non-trivial in size, but smaller than the effect of having a conservative political ideology.

Model 2 adds explicit and symbolic racism into the equation for each of the three outcomes. The most striking finding here is that symbolic racism is strongly associated with each outcome in the expected direction. The standardized coefficients reveal that these are the strongest effects for each equation, including government ensure fairness (-.43), equal opportunity (-.38), and favor the death penalty (.32). These effects persist when controlling for minimizing government, conservative ideology, and Republican, ruling out the principled opposition to government hypothesis. Thus, respondents who buy into symbolic racism are more likely to oppose the government ensuring fairness and equal opportunity and favor the death penalty. In addition, explicit racism has a small but significant effect on government ensure fairness.

But is symbolic racism a mechanism by which race and police injustice produce political outcomes? We address this question by comparing, for each outcome, the race and police injustice coefficients across the two models. Beginning with race, once racism is added to the model, the coefficient for African-American, while still significant, is reduced by more than half for government ensure fairness and equal opportunity, and nearly a third for favor the death penalty. For police injustice, adding racism renders the coefficient for each outcome nonsignificant and trivial in size. Thus, symbolic racism mediates all the effect of police injustice on the three political outcomes, and substantial proportions of the effect of being African-American.

Table 5 presents the results from our analyses of the two dichotomous outcomes. Affirmative action asks about preferential treatment of blacks. Increase crime spending concerns crime but lacks the explicit racial connotation of the death penalty. The models for affirmative action resemble those for government ensure fairness and equal opportunity. Model 1 reveals that race is significantly associated with affirmative action: the odds of favoring affirmative action are more than two times greater $\left(e^{.84}=2.3\right)$ for African-Americans compared to whites. Police injustice is also positively associated with affirmative action: a ten-point increase in black-white police injustice is associated with a $1.2\left(e^{.02 \times 10}=1.2\right)$ increase in odds of supporting affirmative action. Also, as expected, minimize government is strongly negatively associated with support for 
affirmative action, underscoring the importance of the principled opposition to government hypothesis.

Model 2 shows that symbolic racism and explicit racism are negatively associated with being in favor of affirmative action, with symbolic racism exerting the strongest effect in the model. Moreover, racism mediates the effects of African-American and police injustice on affirmative action. Blacks and those who perceive greater police injustice against blacks than whites support affirmative action because they reject explicit and symbolic racist attitudes.

Turning to favoring crime spending, consistent with Meares and Kahan (1998), we find that SES is negatively associated with crime spending, but African-American is not. Also as expected, those favoring minimal government oppose increasing spending on crime, but perceptions of police injustice exert no effect on crime spending. Finally, symbolic racism, but not explicit racism, exerts a significant positive effect on crime spending. Those who espouse modern racist attitudes favor increasing expenditures on crime control. Thus, although blacks and whites do not differ on favoring increased crime spending, and perceptions of black-white police injustice has little effect, those espousing symbolic racism tend to favor spending more on crime.

\section{CONCLUSIONS}

Our analyses yield four principal results. First, compared to whites, African Americans perceive substantially greater police bias against blacks versus whites. Second, with the exception of crime spending, perceptions of police injustice are associated with each political outcome in the expected direction. Third, the effects of perceived police injustice on affirmative action and support for the death penalty are largely mediated by symbolic racism, which has the largest effect on racial policies and the death penalty. These effects persist when opposition to large government is controlled, supporting our principal theoretical mechanism. Fourth, black-white differences in outcomes related to affirmative action are in part explained by perceived injustice and symbolic racism.

We consider these results to be exploratory and effects not causal due to limitations in our research design. We have followed research on racism and political outcomes in making strong assumptions about the causal ordering of racism, police injustice, and political outcomes, while drawing inferences from essentially cross-sectional data. Perhaps most questionable is the assumption of no feedback from racism to police injustice. Yet, it is conceivable that racists are less likely to perceive police injustice. Estimating this effect from the data is not possible because we lack instrumental variables that affect police injustice but not racism, and vice versa. We can, however, use a sensitivity analysis to constrain the feedback to a specific value — or more precisely, a nonlinear function of the opposite effect - and examine the robustness of our results for outcomes measured on an interval scale (using a maximum likelihood estimator with nonlinear constraints on coefficients, e.g., Jöreskog and Sörbom 1996-2001). If we vary the feedback effects of explicit and symbolic racism on police injustice to range from zero to half the size of the effect of police injustice on explicit and symbolic racism, respectively, the overall results remain the same. The effects of police injustice on symbolic racism remain among the largest in the model, and racism mediates about two-thirds of the effect of police injustice on racism. We also examined possible feedback from political outcomes to symbolic prejudice. Again, we find our results robust: if we vary the feedback effect from zero to half the size of the opposite effect (racism on political outcomes), we find that the effect of symbolic racism on political outcomes remains the largest in each model, and mediates about one-half of the effect of police injustice on political outcomes. Although these analyses suggest that our results are robust, future research calls for a longitudinal study, to address this endogeneity problem . 
Nevertheless, our results shed light on the process by which perceptions of police injustice, contemporary racism, and racial politics are interrelated. Our finding that symbolic racism exerts the strongest effects on our outcomes related to equalizing racial social inequities, the death penalty, and spending on crime, and mediates the effects of police injustice has three important implications. First, it points to the potential utility of integrating group conflict theories of crime and group position theories of racism. From the standpoint of group conflict theories of crime, race defines a historically central axis of group conflict, coercion, and domination. From the standpoint of group position theories of race, group conflict lies at the core of the axes of domination-submission and inclusion-exclusion, and is central to the notion of perceived group threat. Second, it supports the general notion that racial injustice by the criminal justice system helps shape public attitudes about the legitimacy of institutions and helps induce support for policies to change those institutions (e.g., Tyler 2003). Clearly, racial discrimination has substantial negative externalities. Third, it underscores the importance of public attitudes about race in the production of public opinion about racial policy. Those attitudes — and in particular, subtle forms of contemporary racism - are implicated not only with explicitly race-targeted policy outcomes, but also race-neutral crime policies. Such findings are particularly important in the contemporary political arena in which parties clamor for increasingly punitive crime policies, alarming numbers of African American males find themselves behind bars, and the legitimacy of the political system is increasingly questioned (Bobo and Thompson 2006). 


\section{REFERENCES}

The American National Election Studies. The 2004 National Election Study [dataset]. Ann Arbor, MI: University of Michigan, Center for Political Studies [producer and distributor].

The American National Election Studies. The 2006 ANES Pilot Study Full Release [dataset]. Stanford University and the University of Michigan [producers and distributors].

Blumer, Herbert . 1958. "Race Prejudice as a Sense of Group Position." Pacific Sociological Review 1:3-7.

. 1965. "The Future of the Color Line." Pp. 322-328 in The South in Continuity and Change. Edited by J.C. McKinney and E.T. Thompson. Surham, NC: Seeman.

Bobo, Lawrence. 1983. "Whites' Opposition to Busing: Symbolic Racism or Realistic Group Conflict?" Journal of Personality and Social Psychology 45:1196-1210.

Bobo, Lawrence D., and Devon Johnson. 2004. "A Taste for Punishment: Black and White Americans' Views on the Death Penalty and the War on Drugs. Du Bois Review: 1:151-180.

Bobo, Lawrence, James R. Kluegel, and Ryan A. Smith. 1997. "Laissez-Faire Racism: The Crystallization of a Kinder, Gentler, Antiblack Ideology." Pp. 15-41 in Racial Attitudes in the 1990s: Continuity and Change. Edited by Steven A. Tuch and Jach K. Martin. Westport, Conn.: Praeger.

Bobo, Lawrence D., and Victor Thompson. 2006. "Unfair by Design: The War on Drugs, Race, and the Legitimacy of the Criminal Justice System." Social Research 73:445-472.

Bonilla-Silva, Eduardo. 1997. "Rethinking Racism: Toward a Structural Interpretation." American Sociological Review 62:465-480.

Brooks, Richard R. W., and Haekyung Jeon-Slaughter. 2001. "Race, Income, and Perceptions of the U.S. Court System.” Behavioral Sciences and the Law 19: 249-264.

Du Bois, W.E.B. [1903] 1973. The Souls of Black Folk. Millwood, N.Y., Kraus-Thomson Organization Ltd.

Hagan, John and Celesta Albonetti. 1982. "Race, Class and Perceptions of Criminal Injustice in America." American Journal of Sociology 88:329-355.

Hagan, John, Carla Shedd, and Monique Payne. 2005. "Race, Ethnicity, and Youth Perceptions of Criminal Injustice.” American Sociological Review 70:381-407.

Jöreskog, Karl G., and Dag Sörbom. 1996-2001. LISREL 8: User's Reference Guide. Lincolnwood, IL: Scientific Software International.

Kinder, Donald R., and David O. Sears. 1981 "Prejudice and Politics: Symbolic Racism Versus Racial Threats to the Good Life." Journal of Personality and Social Psychology 40:414-431.

Kinder, Donald R., and Tali Mendelberg. 2000. "Individualism Reconsidered: Principles and Prejudice in Contemporary American Opinion." Pp. 44-74 in Racialized Politics: The Debate About Racism in America. Edited by David O. Sears, Jim Sidanius, and Lawrence Bobo. Chicago, IL: University of Chicago Press.

Meares, Tracy L., and Dan M. Kahan. 1998. "Law and (Norms of) Order in the Inner City." Law and Society Review 32:805-838.

Omi, Michael, and Howard Winant. 1994. Racial Formation in the United States: From the 1960s to the 1980s. $2^{\text {nd }}$ Edition. New York, NY: Routledge.

Schuman, Howard, Charlotte Steeh, Lawrence Bobo, and Maria Krysan. 1997. Racial Attitudes in America: Trends and Interpretations. Rev. ed. Cambridge: Harvard University Press.

Sears, David O., and P. J. Henry. 2003. "The Origins of Symbolic Racism.” Journal of Personality and Social Psychology 85:259-275.

. 2005. "Over Thirty Years Later: A Contemporary look at Symbolic Racism." Advances in Experimental Social Psychology 37:95-150. 
Sears, David O., P.J. Henry and Rick Kosterman. 2000. "Egalitarian Values and Contemporary Racial Politics." Pp. 75-117 in Racialized Politics: The Debate about Racism in America. David O. Sears, Jim Sidanius and Lawrence Bobo, editors. University of Chicago Press.

Sniderman, Paul M., and Edward G. Carmines. 1997. Reaching Beyond Race. Cambridge, MA: Harvard University Press.

Sniderman, Paul M., and Thomas Piazza. 1993. The Scar of Race Cambridge, MA: Belknap Press/Harvard University Press.

Tyler, Tom R. 1990. Why People Obey the Law. New Haven, Conn: Yale University Press. .2003. "Procedural Justice, Legitimacy, and the Effective Rule of Law." Pp. 283-357 in Crime and Justice: A Review of Research, Vol 30. Edited by M. Tonry. Chicago: University of Chicago Press.

Turk, Austin. 1969. Criminality and the Legal Order. Chicago, IL: Rand McNally.

Weber, Max. 1978. Economy and Society, Vol. 1. Berkeley: University of California Press. 
Black-White Police Injustice (Black minus White):

1. What percent of the BLACK people who are suspected of committing a crime in America do you think are treated fairly by the police? (reversed)

2. What percent of the WHITE people who are suspected of committing a crime in America do you think are treated fairly by the police? (reversed)

Symbolic Racism $(\alpha=.82)$ :

1. Irish, Italians, Jewish and many other minorities overcame prejudice and worked their way up. Blacks should do the same without any special favors.

2. Generations of slavery and discrimination have created conditions that make it difficult for blacks to work their way out of the lower class.

3. Over the past few years, blacks have gotten less than they deserve.

4. It's really a matter of some people not trying hard enough; if blacks would only try harder they could be just as well off as whites.

Explicit Racism $(\alpha=.83)$ :

Where would you rate whites/blacks on a scale of 1-7?

1. Hardworking-Lazy (Black minus White)

2. Intelligent-Unintelligent (Black minus White)

3. Trustworthy-Untrustworthy (Black minus White)

Minimize Government $(\alpha=.73)$ :

1. Government has become bigger over the years because it has gotten involved in things that people should do for themselves (versus because the problems we face have become bigger).

2. The free market can handle today's problems without government being involved (versus we need a strong government to handle today's complex economic problems).

3. Less government is better (versus there are more things that government should be doing).

Republican Party Identification (Strong Democrat to Strong Republican):

Conservative Ideology (Extremely Liberal to Extremely Conservative):

\section{Crime Spending:}

Should federal spending on dealing with crime be increased? (versus decreased or kept about the same)

Death Penalty:

[How strongly] do you favor or oppose the death penalty for persons convicted of murder?

\section{Government Ensure Fairness:}

Should the government in Washington see to it that black people get fair treatment in jobs or is this not the federal government's business?

\section{Affirmative Action}

Are you for preferential hiring and promotion of blacks?

Equal Opportunity $(\alpha=.74)$ :

1. Our society should do whatever is necessary to make sure that everyone has an equal opportunity to succeed.

2. We have gone too far in pushing equal rights in this country.

3. One of the big problems in this country is that we don't give everyone an equal chance.

4. This country would be better off if we worried less about how equal people are.

5. It is not really that big a problem if some people have more of a chance in life than others.

6. If people were treated more equally in this country we would have many fewer problems.

\begin{tabular}{|c|c|c|}
\hline Mean & SD & Range \\
\hline 17.4 & 21.1 & $-30-99$ \\
\hline 45.7 & 26.9 & $0-100$ \\
\hline 28.4 & 20.7 & $0-100$ \\
\hline 3.42 & 1.00 & $1-5$ \\
\hline 3.76 & 1.25 & $1-5$ \\
\hline 3.07 & 1.32 & $1-5$ \\
\hline 3.37 & 1.22 & $1-5$ \\
\hline 3.46 & 1.30 & $1-5$ \\
\hline .68 & 1.09 & $-4.3-5$ \\
\hline .80 & 1.40 & $-3-6$ \\
\hline .65 & 1.17 & $-5-6$ \\
\hline .58 & 1.20 & $-5-5$ \\
\hline .41 & .39 & $0-1$ \\
\hline .44 & .50 & $0-1$ \\
\hline .34 & .47 & $0-1$ \\
\hline .45 & .50 & $0-1$ \\
\hline 2.62 & 2.30 & $0-6$ \\
\hline 3.27 & 1.39 & $0-6$ \\
\hline .65 & .48 & $0-1$ \\
\hline 3.05 & 1.16 & $1-4$ \\
\hline .06 & 1.45 & $-2-2$ \\
\hline .17 & .37 & $0-1$ \\
\hline 3.49 & .77 & $1-5$ \\
\hline 4.41 & .88 & $1-5$ \\
\hline 3.19 & 1.30 & $1-5$ \\
\hline 3.16 & 1.30 & $1-5$ \\
\hline 3.07 & 1.34 & $1-5$ \\
\hline 3.41 & 1.19 & $1-5$ \\
\hline 3.69 & 1.15 & $1-5$ \\
\hline
\end{tabular}


Table 2. Regression of Police Injustice on Demographic and Political Variables

\begin{tabular}{lcrc}
\hline \hline & \multicolumn{1}{c}{$\beta$} & \multicolumn{1}{c}{ SE } & \multicolumn{1}{c}{ std } \\
\cline { 2 - 4 } Age & $-1.04^{* * *}$ & .56 & -.09 \\
Female & $4.73^{* *}$ & 1.72 & -- \\
African-American & $6.91^{*}$ & 2.75 & -- \\
Other Race & 2.68 & 3.09 & -- \\
S.E.S. & $3.98^{* * *}$ & 1.19 & .15 \\
Married & $-4.34^{*}$ & 1.97 & -- \\
\# Children in H-hold & .48 & 1.07 & .02 \\
Republican Party & -.16 & .47 & -.02 \\
Conservative Ideology & $-3.02^{* * *}$ & .75 & -.22 \\
Minimize Government & .86 & 2.41 & .02 \\
Intercept & $31.00^{* * *}$ & 3.34 & \\
$R^{2}$ & \multicolumn{3}{c}{$.11^{* * *}$} \\
\hline${ }^{*} \mathrm{p}<.05,{ }^{* *} \mathrm{p}<.01, * * * \mathrm{p}<.001$ &
\end{tabular}

Table 3. Regression of Racism on Police Injustice and Political and Demographic Controls

\begin{tabular}{|c|c|c|c|c|c|c|}
\hline & \multicolumn{3}{|c|}{ Explicit Racism } & \multicolumn{3}{|c|}{ Symbolic Racism } \\
\hline & $\beta$ & $\mathrm{SE}$ & std & $\beta$ & SE & std \\
\hline Age & $.09 * *$ & .03 & .14 & .03 & .02 & .05 \\
\hline Female & .09 & .09 & -- & -.01 & .07 & -- \\
\hline African-American & $-.77 * * *$ & .14 & -- & $-.79 * * *$ & .11 & -- \\
\hline Other Race & -.02 & .16 & -- & -.01 & .12 & -- \\
\hline S.E.S. & $-.15 *$ & .06 & -.11 & $-.29 * * *$ & .05 & -.20 \\
\hline Married & .06 & .10 & -- & -.01 & .08 & -- \\
\hline \# Children in H-hold & $.11 *$ & .05 & .08 & $.12 * *$ & .04 & .09 \\
\hline Republican Party & $.06 * *$ & .02 & .14 & $.10 * * *$ & .02 & .21 \\
\hline Conservative Ideology & .03 & .04 & .04 & $.09 * *$ & .03 & .12 \\
\hline Minimize Government & -.20 & .12 & -.08 & .19 & .10 & .07 \\
\hline Police Injustice & $-.01 *$ & .00 & -.09 & $-.01 * * *$ & .00 & -.22 \\
\hline Intercept & .11 & .18 & & $2.96 * * *$ & .15 & \\
\hline$R^{2}$ & \multicolumn{3}{|c|}{$.15 * * *$} & \multicolumn{3}{|c|}{$.37 * * *$} \\
\hline
\end{tabular}


Regression of Political Outcomes on Police Injustice, Racism, and Controls

\begin{tabular}{|c|c|c|c|c|c|c|c|c|c|c|c|c|c|c|c|c|c|c|}
\hline & \multicolumn{6}{|c|}{ Gov Ensure Fairness } & \multicolumn{6}{|c|}{ Equal Opportunity } & \multicolumn{6}{|c|}{ Favor Death Penalty } \\
\hline & \multicolumn{3}{|c|}{ Model 1} & \multicolumn{3}{|c|}{ Model 2} & \multicolumn{3}{|c|}{ Model 1} & \multicolumn{3}{|c|}{ Model 2} & \multicolumn{3}{|c|}{ Model 1} & \multicolumn{3}{|c|}{ Model 2} \\
\hline & $\beta$ & SE & std & $\beta$ & SE & std & $\beta$ & $\mathrm{SE}$ & std & $\beta$ & SE & std & $\beta$ & $\mathrm{SE}$ & std & $\beta$ & SE & std \\
\hline Age & .00 & .04 & .00 & .03 & .03 & .03 & .00 & .02 & .01 & .01 & .02 & .02 & -.04 & .03 & -.05 & -.04 & .03 & -.06 \\
\hline Female & $-.22 *$ & .11 & -- & $-.23 *$ & .10 & -- & .05 & .05 & -- & .04 & .05 & -- & -.05 & .09 & -- & -.07 & .09 & -- \\
\hline African-American & $1.03 * * *$ & .18 & -- & $.44^{*}$ & .17 & -- & $.59 * * *$ & .09 & -- & $.27 * * *$ & .08 & -- & $-.92 * * *$ & .14 & -- & $-.65 * * *$ & .15 & -- \\
\hline Other Race & .26 & .20 & -- & .26 & .18 & -- & .17 & .10 & -- & .15 & .09 & -- & -.11 & .16 & -- & -.13 & .16 & -- \\
\hline S.E.S. & .14 & .08 & .07 & -.07 & .07 & -.04 & $.14 * * *$ & .04 & .12 & .05 & .04 & .05 & $-.18 * *$ & .06 & -.11 & -.08 & .06 & -.05 \\
\hline Married & -.04 & .13 & -- & -.04 & .12 & -- & .01 & .06 & -- & .01 & .06 & -- & $.22 *$ & .10 & -- & .19 & .10 & -- \\
\hline \# Children in H-hold & -.08 & .07 & -.04 & .01 & .06 & .00 & -.01 & .03 & -.01 & .03 & .03 & .03 & .07 & .06 & .05 & .03 & .05 & .02 \\
\hline Republican Party & -.05 & .03 & -.07 & .02 & .03 & .03 & $-.05 * * *$ & .01 & -.15 & $-.03 *$ & .01 & -.08 & .04 & .02 & .07 & .02 & .02 & .03 \\
\hline Conservative Ideology & $-.19 * * *$ & .05 & -.18 & $-.12 * *$ & .05 & -.12 & $-.13 * * *$ & .02 & -.23 & $-.09 * * *$ & .02 & -.15 & $.18 * * *$ & .04 & .22 & $.14 * * *$ & .04 & .17 \\
\hline Minimize Government & $-.49 * *$ & .16 & -.13 & $-.43 * *$ & .14 & -.11 & $-.22 * *$ & .08 & -.11 & $-.22 * *$ & .07 & -.11 & -.05 & .12 & -.02 & -.13 & .12 & -.05 \\
\hline Police Injustice & $.01 * * *$ & .00 & .13 & .00 & .00 & .03 & $.01 * * *$ & .00 & .14 & .00 & .00 & .06 & $-.01 * *$ & .00 & -.10 & .00 & .00 & -.03 \\
\hline Explicit Racism & & & & $-.13 *$ & .05 & -.09 & & & & -.05 & .02 & -.06 & & & & -.01 & .04 & -.01 \\
\hline Symbolic Racism & & & & $-.62 * * *$ & .06 & -.43 & & & & $-.30 * * *$ & .03 & -.38 & & & & $.36^{* * *}$ & .05 & .32 \\
\hline Intercept & $.83 * * *$ & .23 & & $2.65 * * *$ & .28 & & $3.91 * * *$ & .11 & & $4.80 * * *$ & .14 & & $2.67 * * *$ & .19 & & $1.67 * * *$ & .24 & \\
\hline$R^{2}$ & & & & & $* * *$ & & & & & & & & & $* * *$ & & & & \\
\hline
\end{tabular}

$* \mathrm{p}<.05, * * \mathrm{p}<.01, * * * \mathrm{p}<.001$

Standardized coefficients $(\mathrm{std})=\left(\mathrm{s}_{\mathrm{k}} / \mathrm{s}_{\mathrm{y}}\right) \beta_{\mathrm{k}}$, where $\beta_{\mathrm{k}}$ is the $\mathrm{k}^{\text {th }}$ coefficient, and $\mathrm{s}_{\mathrm{y}}$ and $\mathrm{s}_{\mathrm{k}}$ are the standard deviations of the dependent variable and the $\mathrm{k}^{\text {th }}$ independent variable.

\section{Table 5. Logistic Regression of Political Outcomes on Police Injustice, Racism, and Controls}

\begin{tabular}{|c|c|c|c|c|c|c|c|c|c|c|c|c|}
\hline & \multicolumn{6}{|c|}{ Affirmative Action } & \multicolumn{6}{|c|}{ Increase Crime Spending } \\
\hline & \multicolumn{3}{|c|}{ Model 1} & \multicolumn{3}{|c|}{ Model 2} & \multicolumn{3}{|c|}{ Model 1} & \multicolumn{3}{|c|}{ Model 2} \\
\hline & $\beta$ & SE & std & $\beta$ & SE & std & $\beta$ & $\mathrm{SE}$ & std & $\beta$ & $\mathrm{SE}$ & std \\
\hline Age & -.15 & .08 & -.21 & -.10 & .09 & -.15 & .01 & .06 & .02 & .01 & .06 & .02 \\
\hline Female & -.23 & .27 & -- & -.31 & .28 & -- & $.58 * *$ & .19 & -- & $.62 * *$ & .19 & -- \\
\hline African-American & $.84 *$ & .34 & -- & .11 & .39 & -- & .22 & .33 & -- & .48 & .36 & -- \\
\hline Other Race & -.08 & .46 & -- & -.14 & .50 & -- & -.09 & .33 & -- & -.05 & .33 & -- \\
\hline S.E.S. & $-.37^{*}$ & .18 & -.23 & $-.71 * * *$ & .20 & -.40 & $-.53 * * *$ & .13 & -.32 & $-.45 * *$ & .14 & -.28 \\
\hline Married & .16 & .30 & -- & .20 & .32 & -- & .38 & .22 & -- & .43 & .22 & -- \\
\hline \# Children in H-hold & $-.62 *$ & .25 & -.39 & $-.54 *$ & .26 & -.35 & -.17 & .11 & -.13 & -.20 & .12 & -.15 \\
\hline Republican Party & $-.20 * *$ & .08 & -.38 & -.08 & .08 & -.16 & .02 & .05 & .05 & .00 & .06 & -.01 \\
\hline Conservative Ideology & $-.27 *$ & .12 & -.32 & -.16 & .13 & -.20 & .05 & .08 & .08 & .02 & .09 & .03 \\
\hline Minimize Government & $-1.71 * * *$ & .45 & -.49 & $-1.75 * * *$ & .48 & -.50 & $-.78 * *$ & .26 & -.27 & $-.97 * * *$ & .27 & -.32 \\
\hline Police Injustice & $.02 * *$ & .01 & .41 & .01 & .01 & .16 & .00 & .00 & .10 & .01 & .01 & .17 \\
\hline Explicit Racism & & & & $-.44^{*}$ & .18 & -.36 & & & & -.12 & .10 & -.12 \\
\hline Symbolic Racism & & & & $-.71 * * *$ & .19 & -.52 & & & & $.37 * *$ & .12 & .46 \\
\hline Intercept & .46 & .50 & & $2.40 * * *$ & .72 & & .16 & .38 & & -.92 & .53 & \\
\hline
\end{tabular}

$* \mathrm{p}<.05, * * \mathrm{p}<.01, * * * \mathrm{p}<.001$

Standardized coefficients $(\mathrm{std})=\exp \left(\mathrm{s}_{\mathrm{k}} \beta_{\mathrm{k}}\right)-1$, where $\beta_{\mathrm{k}}$ is the $\mathrm{k}^{\text {th }}$ coefficient and $\mathrm{s}_{\mathrm{k}}$ is the standard deviation of the $\mathrm{k}^{\text {th }}$

independent variable. 


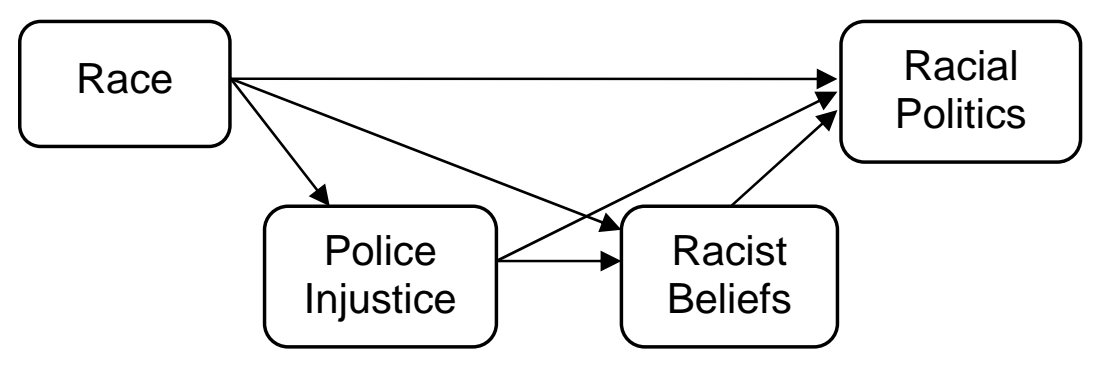

Figure 1. Diagram of Conceptual Model 